\begin{tabular}{c|c|c}
\hline \hline $\begin{array}{c}\text { Vol. 32(3):255-265 } \\
\text { DOI: } 10.4217 / \mathrm{OPR} .2010 .32 .3 .255\end{array}$ & Ocean and Polar Research & September 2010 \\
\hline \hline
\end{tabular}

\title{
Note
}

\author{
운용해양시스템 구축의 경제적 의의 \\ 이준행 - 노용환 \\ 서울여자대학교 사회과학대학 경제학과 \\ (139-774) 서울시 노원구 화랑로 623
}

\section{A Note on the Economic Rationale for the Development of the Korean Operational Oceanographic System}

\author{
Joon-Haeng Lee and Yong-Hwan Noh \\ Department of Economics, College of Social Sciences \\ Seoul Women's University, Seoul 139-774, Korea
}

\begin{abstract}
This study evaluated economic feasibility and provided rationale for the development of the Korean Operational Oceanographic System (KOOS). KOOS is supposed to be established for the preservation and management of marine environments, and for the safety of ocean activities. Economic issues associated with operational oceanographic systems are discussed. During the operational period of KOOS associated with conservative small-input scenarios, and according to the macroeconomic inputoutput analysis, the system was estimated to generate 8.3 times its actual proposed economic investment (about KRW 327.7 billion). Other rationales that cannot be easily quantified were also discussed.
\end{abstract}

Key words : Operational oceanography, Economic feasibility, Input-output analysis

\section{1. 서 론}

지구온난화등 기상변화가 빠르게 진행되면서 기상이 변·해수면상승·농작물피해·물부족 문제가 정치·경제· 사회적인 이슈로 부상하고 있다. 그리고 이러한 생태계의 변화는 국내외 경제시스템의 변화를 요구하고 있다. 산업 별 차이는 있으나 기후변화로 산업내 미래 손실에 미치는 영향이 심대해 질 수 있다는 인식이 팽배해 있다(김과 황 2008; 한 2007). 매년 기상재해에 대한 피해보고서를 발간 하고 있는 MunichRe사는 세계적으로 자연재해로 인한 경 제적 손실이 지난 40년간 7배 증가하였고, 피보험 손해는 14 배나 증가한 것으로 분석하면서 기후변화로 인해 경제 적 피해를 전망하고 있다. 기후변화는 1차 산업에 직접적

\footnotetext{
*Corresponding author. E-mail : yhnoh@swu.ac.kr
}

인 영향을 미침은 물론 소비재 수요패턴의 변화를 통해 2차 산업에 영향을 미치기도 하며, 보험업을 비롯한 서비 스업에도 영향을 미칠 수 있다(예컨대 한 2007; 노와 유 2009).

따라서 오늘날 국가는 국민후생 증진을 위해 경제성장 이라는 기본적인 토대 구축 외에도 환경문제의 해결과 국 민의 공공안전보장 강화라는 기본적인 책무에 직면해 있 다. 환경변화의 평가-예측 및 국민의 생명과 재산 보호를 위한 국가의 역할이 강조되고 있으며, 특히 삼 면이 바다 로 둘러싸인 우리나라의 경우 국가의 해양과 연안자원 관 리를 위한 역할이 매우 중요하다.

최근 기후변화로 태풍의 강도 및 내습빈도가 증가하여 예상치 못한 막대한 인명-재산상 피해가 우려되고 있는 바, 연안의 자연재해로부터 국민의 재산과 인명을 보호해 야 한다는 요구가 고조되고 있다. 또한 허베이 스프리트호 
해양오염사고(2007.12), 천안함 침몰사건(2010.3) 등 우리 해역에서 발생하는 해양사고의 수습과정에서 정확한 실시 간 해양정보는 필수적이다. 특히 이러한 자연재해 및 인 재의 예방과 사후처리 과정에서는 국지정밀 기상모델, 정밀격자 해상상태 예측체계 구축, 연안순환 예측모델과 같은 해양 정보에 대한 종합적인 관측시스템을 구축하여 최종수요자에게 구체적인 해양정보를 제공하는 것이 중 요하다.

그러나 현행 기상예보 시스템은 내륙 중심으로 이루어 지고 있어 환경이 급변하는 해양 관련 전문예보로는 많이 미흡한 실정이다. 따라서 기존의 해양정보를 통합하여 수 요자 중심의 단기정보로 가공하여 제공하는 것이 필요하 다. 연안재해, 해양오염사고, 안전항해 지원 등 해양에서의 문제를 해결하고 해양관련 국가기관 - 산업체 - 민간이 각종 해양활동에 필요로 하는 해양환경에 대한 예측 정보를 생 산·제공하는 운용해양시스템(operational oceanographic system, $\mathrm{OOS})$ 의 구축이 바로 그 것이다.

경제학에서 기후변화 예측과 해양정보서비스는 전통적 으로 '공공재'의 영역에서 다루어져 왔다. 공공재의 특성 상 사회적으로 반드시 필요한 재화임에도 불구하고 경제 주체들이 필요로 하는 만큼 시장에서 충분히 공급되기를 기대하는 것은 어렵기 때문에 이러한 경우 정부의 예산투 입에 의해 시장수요가 충족되어야 한다는 것이 공공부문 에 의한 시장개입의 이론적인 근거이다. 문제는 시장실패 에 대한 정부개입의 논리적 근거가 예산운용의 우선순위 와 예산투입 수준의 적정성 문제에 대한 의문까지 해소시 켜 주는 것은 아니라는데 있다.

따라서 본 연구에서는 해양예측 데이터 수집 및 정보제 공의 경제적 가치를 수요자 측면에서 살펴하고, 운용해양 시스템 구축 사업이 국민경제에 미치는 파급효과를 분석 한다. 그리고 모든 예비타당성조사 대상 사업에 공통적으 로 적용되는 기본평가항목과 운용해양시스템이라는 고유 사업에만 적용되는 사업특수 평가항목으로 구분하여 운용 해양시스템 구축 사업의 정책적 타당성을 평가해 본다.

이를 위해 다음에서는 먼저 연안·해양경제와 운용해양 시스템의 중요성을 기술한다. 이어서 운용해양시스템 개 발 및 구축 사업의 경제적 편익 요인을 도출하고, 국내외 운용해양시스템 관련 기술동향과 추진실적을 검토한다. 마지막으로 동 시스템의 개발-구축 과정과 운영단계에서 의 경제적 파급효과 및 정책적 가치를 평가하고 결론을 맺는다.

\section{2. 연안·해양경제와 운용해양시스템의 중요성}

해양은 우리에게 음식·여가 및 인간생활을 풍요롭게 해주는 다양한 기회를 제공해 주지만, 한편으로는 정확한
예측 정보를 가지고 있지 못할 경우 재난 등의 위험을 초 래하기도 한다. 특히 삼면에 바다로 둘러싸인 우리나라의 경우 해양은 인간생활과 밀접할 뿐만 아니라 산업적 측면 에서 매우 중요하다. 해양생태 수요, 항만이용 물동량, 해 운여객, 어업종사자 등 측면에서 운용해양시스템의 순기 능이 우리나라의 연안·해양경제에 미치는 영향을 무시할 수 없다.

우리나라의 수산물 유통-가공 등의 부가가치를 제외한 연간 순수 어업생산액은 2008년 현재 6조 3,708억원 수준 으로 국가 전체의 총부가가치에서 어업이 차지하는 비중 은 $0.24 \%$ 수준(부가가치 총액규모는 2 조 1,740 억원)이다. 어업 생산량은 2008 년 현재 연근해 128 만 6 천톤, 천해양 식 138 만 2천톤, 원양 66 만 5 천톤, 내수면어업 2만 9천톤 등으로, 동 실적은 태풍·적조 등 자연재해와 유류오염사 고와 같은 인재에 민감한 편이다.

한편 국토해양부(http://www.mltm.go.kr)「항만운영정 보시스템」에 따르면 2008년도 우리나라의 항만을 이용 한 수출입 물동량은 7억 5,292만톤 수준으로 국가경제 발 전에 중요한 요인이 되고 있다. 국토해양부 「한국해운조 합자료」에 의하면 국내 해운여객 수송실적은 2008년 1,416 만 2 천명 수준으로 도서인구의 경제활동과 해양 관 광수요에 중요한 요인이다. 또한 통계청(http://www. kostat.go.kr)「어업기본통계조사」와「어가경제통계」에 의하면 2008년말 현재 국내 어가인구는 19 만 2 천명으로 가구당 어가소득은 연간 3,117만 6천원 수준이다.

운용해양시스템의 직접적인 경제적 가치는 예보시스템 구축으로 기대되는 해양에서의 재난 및 안전사고로 인한 피해저감 효과를 통해서 가늠해 볼 수 있다. 안전사고로 인한 피해는 해양에서 어선·여객선·유조선 등의 전복· 침몰 등 1 차 사고와 해양사고로 인한 인명·해양오염 등 2차 피해를 포함한다. 예를 들어 1904-2008년 기간 중 우 리나라에 영향을 준 태풍 수는 연평균 3.1개에 달하며, 1995-2008년 기간 중 연간 평균적인 인명피해는 103.7 명,

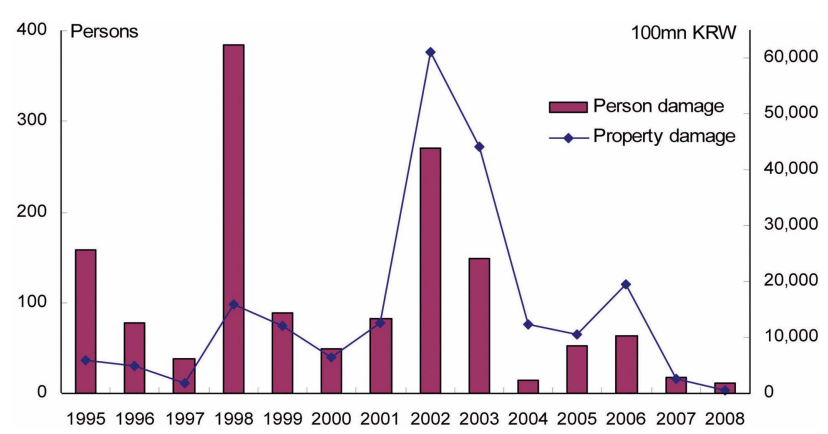

Note: Based on current price.

Source: Korean National Emergency Management Agency, Yearly Disaster, each issues.

Fig. 1. Natural disaster of Korea. 
재산피해는 1 조 5,030 억원에 달한다(Fig. 1 참조).

우리나라 해역에서는 태풍, 안전부주의, 선체노후화 등 이 원인이 되는 해양오염사고도 끊임없이 발생하고 있는 데, 지난 10 여년간 연평균 300 건 이상 발생해 왔으며, 선 박의 대형화와 해상운송량의 증가로 기름유출 가능성이 상존하고 있으므로 철저한 예방대책이 강구되어야 한다. ${ }^{1)}$ 또한 우리나라는 태풍·농무·해일 등 반복성·기상이변 성 해양재난에 대한 대비와 함께 향후 동북아 물류중심기 지로써 해상교통량 증가에 따른 한반도 주변해역의 해상 안전 체계를 강화할 필요가 있다. 우리나라의 선박등록 척 수 대비 해양사고 발생률은 $0.8-1 \%$ 수준으로 높은 편인 데, 해난사고는 1999-2008년 기간 중 연평균 800척 내외 로 2008년의 경우 총 767척이 발생하여 49명(사망 16, 실종 33$)$ 의 인명피해와 약 180 억원의 재산피해를 기록하 였다.

\section{3. 운용해양시스템 구축의 경제적 편익}

운용해양시스템은 유류오염확산 예측, 적조확산 예측, 어로작업 및 안전항해 지원, 연안재해 대응, 군작전, 수색 구조, 연안 - 해양공사 지원, 해양관광, 레저지원 등 다양 한 분야에서 활용이 가능하다. Willis (2009)에 의하면 해 양자료는 다음 Table 1과 같은 산업부문에서 관측자료 수 요자의 경제적 편익을 증대시킬 뿐만 아니라 연안의 자연 재해로부터 국민의 재산과 인명을 보호하는데 기여한다.

운용해양시스템이 제공하는 정보의 가치는 최종수요자 의 후생증가를 통해 나타난다. 운용해양시스템의 구축비 용도 해양 관련 자연재해, 인적재난, 사회적 재난의 감소 라는 피해저감효과를 통해 보상받게 될 뿐만 아니라 거시 경제적으로는 연구개발 및 운영의 국민경제적 파급효과를
통해 상쇄될 수 있다.

운용해양시스템의 운영을 통한 해양 및 연안에서의 예 보능력 제고는 경제적으로 해양에서의 자연재해 경감 및 위기관리 능력 향상, 국민 보건과 건강 증진, 해양생태계 복원, 생물다양성 보전 등 경제성장과 국민의 생명-재산 보호에 기여함을 의미한다. 운용해양시스템의 구축으로 정부기관과 민간기업, $\mathrm{NGO}$, 과학-교육계 등 광범위한 사 용자 집단에게 해양환경 및 예측정보의 지속적인 제공을 통해 해일·해수범람·태풍 등에 의한 연안 해양재해, 해 양환경, 유류오염, 적조 등에 대한 신속한 예방 대책 수립 으로 피해 저감효과를 시현할 수 있음은 물론 직·간접적 인 경제적 가치를 창출할 수 있다.

Fig. 2는 운용해양시스템의 구축과 정상운영으로 창출 된 가치가 정보의 최종 수요자에게로 전달되는 과정에서 경제적 가치가 누적되는 과정을 예시하고 있다. 즉 최초에 운용해양시스템의 구축과 운영으로 창출된 가치는 핵심 관측시스템 및 정보전달시스템 창출의 기술적 가치를 시 현하게 되고, 정상운영 단계에서는 실시간 자료전송 및 관 리를 통해 수집된 해양정보를 수치모델링 분석 등을 통해 최종 사용자 요구에 맞추어 재가공하며, 이렇게 생산된 정 보는 각 생산활동 부문에 유용하게 이용됨으로써 가치가 누적적으로 증가하게 된다.

한편 운용해양시스템은 기후변화, 해양서비스, 자연재 해, 국가안전, 공중위생, 생태계 건강 및 생물해양자원에 관련된 예측능력 향상에 크게 기여할 것으로 예상된다. 신 속한 해양환경의 평가와 변화의 탐지, 미래 해양 환경에 대한 정확한 예측을 위해 요구되는 자료와 정보를 제공함 으로써 해양환경 보전, 해양자원 보전, 기후변화 영향 대 응, 자연재해 저감 등 다양한 경제적 이익을 창출할 것으 로 기대된다. 해양환경 예측 관련 정보가 창출하는 경제적

Table 1. Demand sectors for the operational oceanographic system

\begin{tabular}{|c|c|c|c|}
\hline Energy & Environment & Safety & Business \\
\hline $\begin{array}{l}\text { - Wind power } \\
\text { - Hydroelectric generation } \\
\text { - Electricity power generation } \\
\text { - Offshore power generation } \\
\text { - Energy forecasting }\end{array}$ & $\begin{array}{l}\text { - } \mathrm{CO}_{2} \text { emission policy } \\
\text { - Climate prediction } \\
\text { - Meteorological service } \\
\text { - Hydrological services } \\
\text { - Scientific research } \\
\text { - Environmental education }\end{array}$ & $\begin{array}{l}\text { - Storm forecast } \\
\text { - Search and rescue } \\
\text { - Oil spill response } \\
\text { - Water quality } \\
\text { - National defense }\end{array}$ & $\begin{array}{l}\text { - Weather forecast } \\
\text { - Tourism } \\
\text { - Recreation } \\
\text { - Oil and gas production } \\
\text { - Trade } \\
\text { - Transportation } \\
\text { - Fisheries } \\
\text { - Matitime operations }\end{array}$ \\
\hline
\end{tabular}

Source: Based on Willis (2009).

\footnotetext{
1)특히 2007년에 태풍과 태안 앞바다에서 발생한 허베이 스프리트호 해양오염사고(2007.12.7)로 인한 기름유출량은 $14,021.8 \mathrm{k} /$ 에 달 하며, 피해지역이 충청남도(어장피해 11 개 읍·면 473 개소 5,159 ha, 해수욕장 4 개면 15 개소), 전라남도(김양식장 7,905 ha, 마을어 장 $14,356 \mathrm{ha}$ ), 전라북도(양식어업 $1,831 \mathrm{ha}$, 기타 1,305 건)에 걸쳐 대규모로 나타났고, 사고와 관련해 지출한 비용만 해도 긴급생계 지원금 1,172 억원(국비 768 억원, 도비 150 억원, 성금 254 억원), 피해주민 보상금 112 억원, 생계안정 특별공공근로 지원 200 억원 등 으로 잠정 집계된 바 있다.
} 


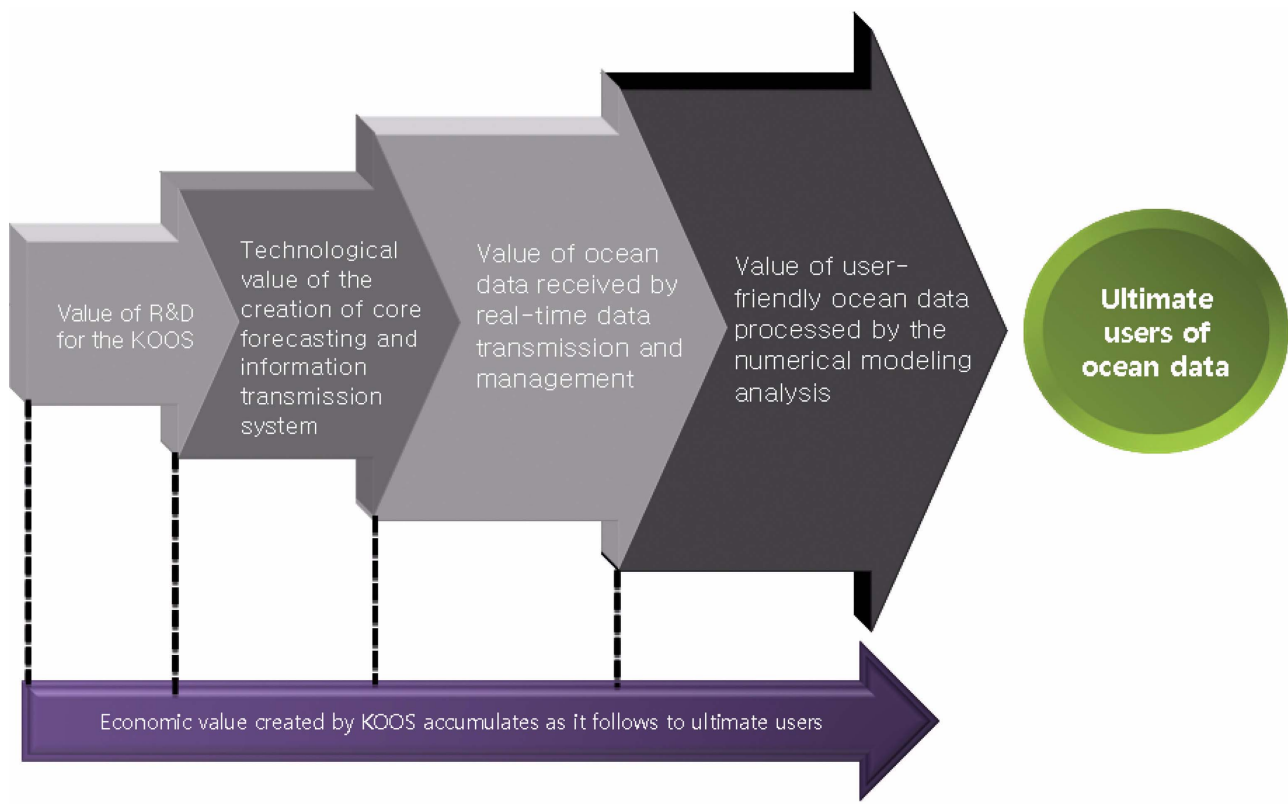

Fig. 2. Economic value for the development of the Korean Operational Oceanographic System (KOOS).

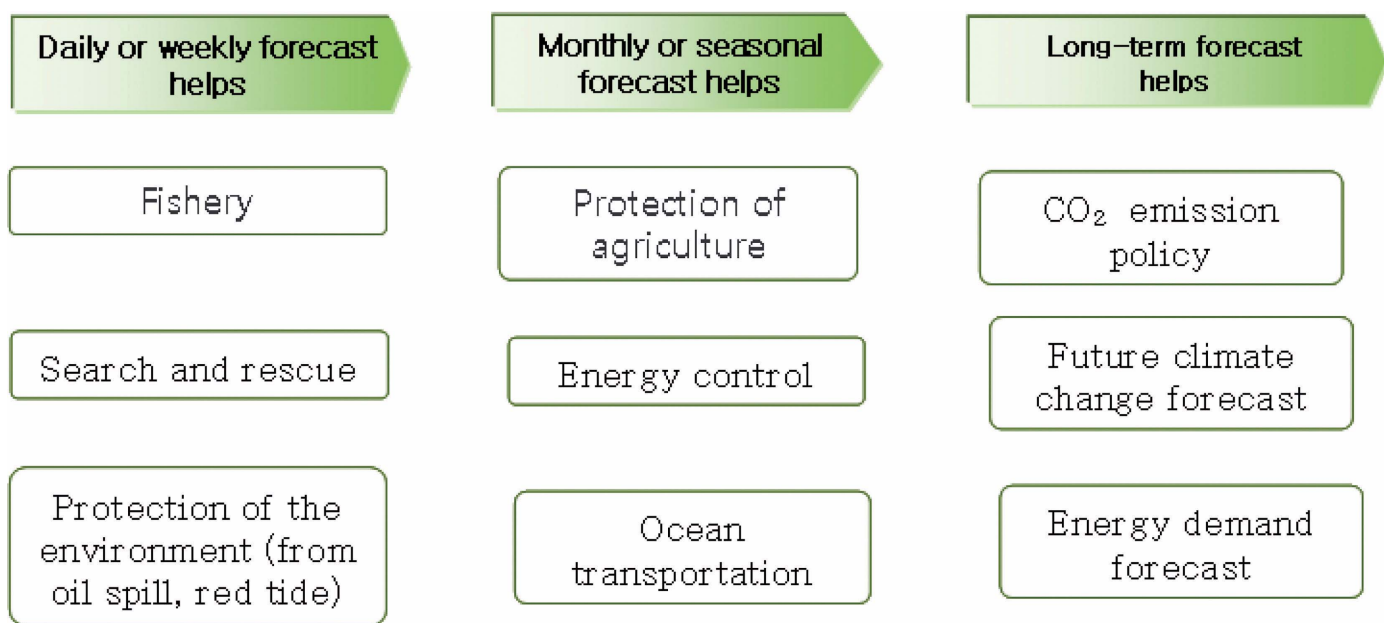

Fig. 3. Economic value of KOOS according to forecasting interval.

이익을 예측시간 단위에 따라 예시하면 Fig. 3과 같다. 기후변화로 인한 자연재해의 증가와 자연환경에 대한 예측의 불확실성 증대가 한 국가의 경제에 유의한 영항을 미친다는 것은 이미 환경경제학자들 사이에서 정설로 자 리 잡은지 오래다. 그런데 기후 예측을 위해서는 해양에 대한 이해가 필수적이므로 해양예측 시스템의 예측능력 향상은 곧 경제적 이익으로 직결된다. 미국의 경우 엘니뇨 예측능력의 향상으로 농업부문에서만 연간 2.7억-3억 달 러의 경제적 편익을 추구하고 있는 것으로 추정된 바 있 다(Kite-Powell et al. 2003). 호주의 경우는 2006년 현재 기후에 민감한 농업, 어업, 석유-가스와 같은 에너지 산 업 분야를 중심으로 해양관측시스템으로부터의 총 편익이
6.2억 달러에 달한 반면, 동 시스템을 운영하는데 소요된 비용은 2,730 만 달러에 불과해 비용대비 편익비율이 무려 22.6배에 달하는 것으로 추정된 바 있다(Australian Academy of Technological Sciences and Engineering 2006).

관광, 건설, 수도, 정부서비스, 금융·보험, 보건 등의 경 제활동부문 역시 직·간접적으로 기후에 의해 영향을 받 는 주요 산업으로 이들 부문에서 해양예측시스템의 중요 성은 날로 커지고 있다. 운용해양시스템의 구축 - 운영으 로 이들 산업의 발전을 통해 새로운 일자리가 창출되고, 관련 산업의 수익 증가는 다시 세수증가로 이어져 국가재 정의 확충 및 국민경제 전반에 걸친 발전에 도움을 줄 것 
Table 2. Potential industrial benefits of using KOOS

\begin{tabular}{|c|c|}
\hline Industry & Examples of benefits \\
\hline Agricultural products & - Planting and harvest decisions increase crop yield \\
\hline Fishery products & $\begin{array}{l}\text { - Use weather information to increase efficiency } \\
\text { - Useful for aquaculture by providing information about the changes in stream flow }\end{array}$ \\
\hline Apparels and fibers & - Useful for the apparel design \\
\hline Precision instruments & $\begin{array}{l}\text { - Development of the precision instrument sectors in the process of accurate weather and marine } \\
\text { forecast }\end{array}$ \\
\hline Electric services & - Useful for the estimation of energy demand \\
\hline Gas and water supply & - Better management of water supplies \\
\hline $\begin{array}{l}\text { Building construction } \\
\text { and civil enginering }\end{array}$ & - Adjust construction schedules according to weather forecast (especially, for the ocean areas) \\
\hline \multicolumn{2}{|l|}{$\begin{array}{l}\text { Eating and drinking places, and } \\
\text { hotels and other lodging places }\end{array}$} \\
\hline Land transport & $\begin{array}{l}\text { - Improve recreational activities and increase safety in coastal areas by predicting conditions that } \\
\text { make ocean recreation dangerous }\end{array}$ \\
\hline \multicolumn{2}{|l|}{$\begin{array}{l}\text { Water transportation Air } \\
\text { transportation }\end{array}$} \\
\hline Finance and insurance & $\begin{array}{l}\text { - Better to estimate risk due to climate variability } \\
\text { - Create weather derivative markets }\end{array}$ \\
\hline Research services & $\begin{array}{l}\text { - Development of the forecasting technology associated with ocean weather } \\
\text { - Development of the rapid action due to oil pollution, search and rescue, red tide in ocean areas } \\
\text { - Promote related professional researchers }\end{array}$ \\
\hline Professional business services & $\begin{array}{l}\text { - Active participation in the relevant scientific activities associated with the establishment of } \\
\text { NEAR-GOOS }\end{array}$ \\
\hline Other business services & - Invigoration of providing ocean information services \\
\hline $\begin{array}{l}\text { Public administration and } \\
\text { defense }\end{array}$ & $\begin{array}{l}\text { - Improve natural disaster management and preventive health measures } \\
\text { - Useful for national defense, military operation, and marine safety and rescue }\end{array}$ \\
\hline Medical and health services & $\begin{array}{l}\text { - Providing health and community services in response to the likelihood of a disease outbreak due } \\
\text { to climate variability }\end{array}$ \\
\hline
\end{tabular}

으로 기대된다. 미국의 경우 IOOS(Integrated Ocean Observing System)의 운영으로 각 주별로 전체 산업부문 에서 발생하는 경제적 가치가 해마다 증가하는 것으로 평 가되고 있다(Willis 2009).

해양환경과 기후변화에 민감한 경제부문과 운용해양시 스템을 이용한 이들 경제활동 부문에서의 잠재적인 편익 을 산업연관표(중분류 기준)에 따라 예시해 보면 다음 Table 2와 같다.

\section{4. 운용해양시스템의 비전}

해양환경의 보전, 해양생태계의 보전과 연안에서의 자 연재해 저감 및 인간활동 지원이 세계 각국의 주요 관심 사항이 되고 있다(이 등 2009). 미국·일본·유럽 등 선진 국은 1990년대 초부터 운용해양시스템을 목표로 하는 국 가차원의 통합적인 해양관측망(실시간 관측과 수치모델링 을 연계한 운용해양시스템) 구축 계획을 수립하여 실용화 하였으며, 이미 현장 관측과 수치예측모델, 원격탐사 등의
기술이 상호 연계되어 체계적인 연안정보를 생산하는 운 용해양시스템이 활발하게 작동되고 있다.

우리나라도 동북아 주변 해역에 대한 효과적인 운용해 양시스템의 구축을 통해 포괄적인 해양예보 능력을 제고 함으로써 해양에서의 자연재해 경감, 국민의 보건과 건강 증진, 해양생태계 보호 등 국민의 생명과 재산 보호에 적 극적인 자세를 견지할 필요가 있다. 정부기관과 다양한 민 간부문에게 도움이 되는 해양정보의 지속적인 공급을 통 해 경제적 편익을 창출해 낼 수 있을 것이기 때문이다.

국토해양부는 운용해양시스템의 인프라 구축을 위해 실 시간 국가해양관측망 기본계획 (2001)을 수립하여 국립해 양조사원, 국립수산과학원, 한국해양연구원, 기상청, 관련 산업계, 각 지방자치단체와 공동으로 해양관측망을 구축 해 왔다. 2008년말 현재 약 82개소의 실시간 해양관측소 가 설치 운영되고 있으며, 2010년까지 약 91개소의 실시 간 해양관측소 구축을 통해 실시간 국가해양관측망을 구 축할 계획으로 우리나라 연안정보 생산 제공을 위한 인프 라를 구축 중에 있다. 
국내의 해양현장 모니터링 및 예측기술은 한국해양연구 원을 중심으로 기술적 발전을 이루어와 실시간 해양모니 터링에 활용할 수 있게 되었으며, 이를 해양모델과 연계하 는 활용화의 가능성도 제고되었다.

그러나 지금까지 국내 해양관련 기관에서 수행하는 해 양조사는 수요자가 필요로 하는 해양예보시스템으로 연결 되지 못하여 해양 관련 정부기관, 해양산업체 및 국민의 해양에서의 각종 활동을 충분히 지원하지 못하고 있다. 해 양정보의 수요자인 해양 관련 정부기관·산업체·일반대 중이 각종 해양활동에 필요한 정보는 해양의 현황과 미래 에 대한 예측정보이며 최근의 해양관측이 운용해양학 분 야로 진전되고 있으나, 우리나라의 경우 운용해양시스템 구축이 미흡하여 해양현황 파악과 예측에 활용되지 못하 고 있다. 조석·해일·파랑 등 연안환경 예측 모델의 도 입·개발은 어느 정도 이루어졌으나, 이를 기상입력 자료 와 연계하여 통합하는 적용체제의 구축은 아직 취약한 것 으로 평가되고 있다.

한편 삼 면이 바다로 둘러싸인 우리의 경우 동해·황해 등 지역해 전체를 하나의 시스템으로 하는 자료의 실시간 교환체제가 필요하나 중국·북한 등과의 실시간 자료교환 이용이 미비한 실정이다. 그러나 전지구관측시스템 (GEOSS)의 모듈인 전지구해양관측시스템(GOOS)의 지 역 프로그램이 운용해양을 위한 시스템으로 진전되어 해 양의 관측-이해 및 예측능력 향상을 통한 실용화가 촉진 될 전망이다. 우리나라도 GEOSS의 효율적 달성을 위해 해양분야의 관측시스템을 유기적이고 통합적으로 운영하 는 시스템을 구축하는 것이 필요하다.

이에 한국해양연구원은 연안재해, 해양오염 사고, 안전 항해 지원 등 해양과 관련된 문제의 해결 및 해양 관련 국 가기관-산업체·민간이 각종 해양활동에서 필요로 하는 해양환경 변화의 현황과 예측정보를 생산·제공하는 「운 용해양(해양예보) 시스템 연구」(2009-2013)를 진행 중에 있다. 연안국지 정밀격자 단위로 해양예측의 기반요소가 되는 조석, 조류, 3차원 순환·수온·염분, 파랑, 폭풍해일 및 기상과 관련된 예측정보를 생산하고, 해양 현황과 예측 정보의 체계적인 생산-제공 체제를 개발-구축하여 이를 활용한 유류오염 확산, 부유사 이동, 수색구조 모델 등을 개발한다는 것이다.

우리의 경우 아직 해양산업이 활성화되지 않아 해양정 보를 사용자가 경비를 들여 입수 활용하는데 까지 도달하 려면 다소 시일이 걸릴 것으로 보인다. 그러나 이미 선진 국의 경우 해양정보를 상품화하는 해양정보산업을 육성하 는 방향으로 추진되고 있다. 해양관측 및 예보기술도 연구 개발 후에는 운용목적의 해양예보기술이 국내에 구축되 고, 실제로 운용되어 많은 이용자의 요구를 충족시킨다면 민간에 기술이전을 통해 보다 다양한 사용자의 요구에 맞
는 결과를 제공할 수 있을 것이다. 이러한 산업화로 기술 집약적인 연구개발 사업체의 참여를 유도할 수 있을 것 이다.

\section{5. 운용해양시스템 구축·운영의 경제적 파급효과}

운용해양시스템은 경제성 있는 사업인가? 동 사업은 사 실 경제성 여부를 떠나 국민의 생명과 재산보호를 위해 반드시 구축되어야 한다. 다만 정부예산이 수반되는 의사 결정이 뒤따르는 만큼 통상적인 범주 내에서 경제성을 평 가해 볼 여지는 있다. 다음에서는 투자의 적절성과 사업추 진에 대한 합리적 판단을 도출하기 위해 이용되는 '투입산출분석'(input-output analysis)에 의한 정량분석과 함께 주요 정책 항목에 대한 타당성 검토를 수반하는 정성평가 를 동시에 수행한다.

\section{투입-산출분석 개요}

일반적으로 한 재화나 서비스의 생산에 있어 각 산업은 원재료의 거래관계를 토대로 직·간접적으로 상호 연관되 어 있으며, 생산활동을 통해 이루어지는 이러한 산업간의 상호의존 관계를 수량적으로 파악하는 분석 방법이 바로 ‘투입-산출분석'(input-output analysis)이다. 운용해양예보 시스템은 다양한 사용자 집단의 요구에 대응한 신속한 자 료와 정보를 생산하여 배포하는 체계적인 시스템을 필요 로 한다. 해양 상태의 적시 예측을 위해서는 요구되는 자 료와 정보를 제공하는 시스템의 구축 개발이 전제되어야 한다. 운용해양시스템의 효율적인 운영을 위해서는 관측 시스템 구축, 정밀기상 예보, 해양예보모델 운영체제 구 축, 연안 해상상태 예보기술 개발, 해양순환 및 연안환경 예보기술 개발, 유류오염·수색구조-적조·환경·생태 활 용기술 개발, 해양정보 전달시스템 구축을 위한 개발비용 의 확보와 함께 관련 산업기술의 발전이 필수적이다.

운용해양시스템은 투자 단계에서 예보 및 활용기술과 관련된 연구개발, 소프트웨어 개발 등 사업관련 전문서비 스, 측정 및 분석 등 정밀기기 부문을 중심으로 집중적인 투자를 필요로 한다. 따라서 동 시스템은 운용단계에서의 직접적인 경제적 편익 외에 상용화 추진 과정에서 발생하 는 사업비가 다른 국민경제활동 부문에 미치는 총산출효 과 및 관련 산업부문에 대한 파급효과를 유발하게 된다.

다음에서는 Fig. 4와 같이 투입-산출분석 과정을 통해 운용해양시스템 구축 사업의 단계별 투자 및 정상운영 초 기단계에서 국내 전 산업부문에 걸친 경제적 파급효과를 분석한다. 이를 위해 한국은행의 「산업연관표」(2007년 연장표 기준자료)를 이용하여 생산, 부가가치, 취업자수 및 재정수입 효과를 계량화하여 그 결과를 소개한다. 즉 생산 및 처분과 관련된 모든 거래내역을 내생변수로 하여 


\section{Input Data/Analyses}

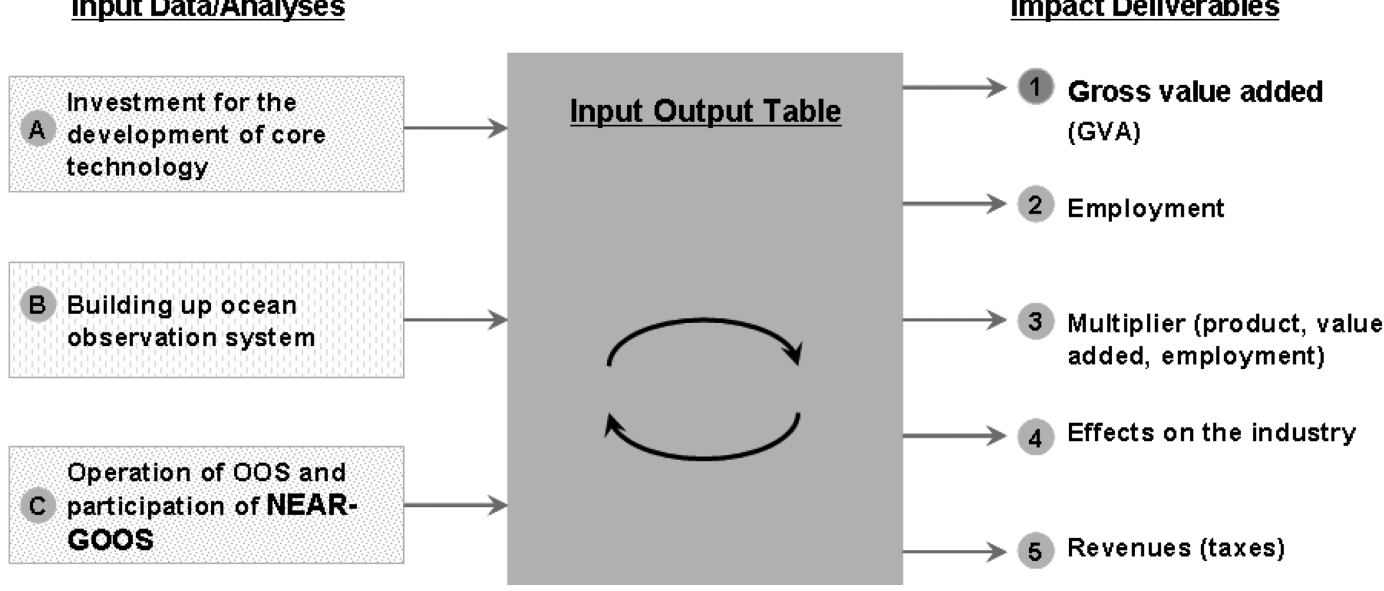

Fig. 4. Input-output analysis flow chart.

내생부문과 관계없이 결정되는 외생부문 값의 변동이 이 들 내생변수 값에 어떠한 영향을 미치는지를 살펴봄으로 써 국민경제적 파급효과를 설명한다.

한편 투입-산출분석은 1년 동안 국민경제 내에서 발생 하는 재화와 서비스의 산업연관표를 이용하여 운용해양시 스템 구축 및 운영 사업의 생산·부가가치·고용 등 측면 에서 국내 산업에 미치는 파급효과를 추정하기 위해서는 통상적으로 단계별 투자소요 금액 및 운용해양예보시스템 서비스 제공과 관련된 산업부문을 내생부문에서 외생부문 으로 이동 설정하여 파급효과 분석을 위한 투입산출구조 로 사용하여야 한다. 그리고 본 연구에서 외생벡터로 고려 할 수 있는 시나리오는 운용해양시스템 구축 및 운영을 위해 (구)해양수산부(2007)가 제시한 2009-2018년 기간 중의 투자소요금액을 394억원을 들 수 있다. 동 투자금액 은 1단계(2009-2012) 기간 중에 시스템 기반기술 연구와 활용예보의 시범운영을 위해, 2단계(2013-2015) 기간 중 에는 연안해상상태 예측의 정상운영과 활용기술개발의 시 범운영을 위해, 그리고 마지막 3단계(2016-2018년)에서는 운용해양시스템의 개발완료 및 정상운영을 위해 사용되어 질 계획이다.

그런데 다음에서 산업연관표를 이용하여 계산하게 될 각종 경제적 파급효과는 사회적 할인율이 고려되지 않은 값으로 해석에 따라 과대추정의 여지를 가지고 있다. 보다 정확한 경제적 파급효과를 측정하기 위해서는 투입 기간 별 세부예산내역과 산업구조 변화를 반영한 산업연관표 예측치가 동시에 제시되어야 한다. 그러나 현실적으로 연 도별 사업비 규모가 작을 뿐만 아니라, 어느 기간에 대한 분석의 경우에도 항상 동일한 2007년도 기준의 산업연관 표를 이용하여야 하는 제약이 따르므로 사실상 연도별 파 급효과를 별도로 구하는 것은 큰 의미가 없게 된다. 따라 서 본고의 경제적 파급효과 계산은 산업구조가 2007년과
동일하다는 가정하에 경상가격 기준으로 제시함으로써 파 급효과의 방향을 가늠해 보는 수준에서 시도한다. 고용창 출효과도 산업구조 변화와 실질임금 추이 등에 따라 파급 효과에 대한 결과가 달라질 가능성을 내포한다는 점을 전 제한다.

\section{운용해양시스템 “투자"의 국민경제적 파급효과}

운용해양시스템 운영준비 및 기초연구기간(2009-2015 년)과 운영기간(2013-2018년) 중의 예산 투입이 생산, 부 가가치, 고용 및 세수에 미치는 국민경제적 파급효과는 다 음과 같다.

첫째, 운영준비 및 기초연구단계 기간 중 연구개발비 및 사업관련 전문서비스 등에 대한 지출 자체의 총생산유 발효과는 실제 소요사업비의 약 2.08 배 수준(458억원)으 로 나타났으며, 사업비가 주로 투입되는 연구부문과 사업 관련 전문서비스 부문을 중심으로 한 서비스업 부문에서 직•간접 파급효과가 큰 것으로 나타났다.

둘째, 운영초기투자기 중 총생산유발 효과는 368억원 규모로 계산되었는데, 이는 실제 투자비의 2.11배 수준에 이르는 규모로서 부문별로는 제조업, 서비스업 부문의 순 으로 생산파급 및 부가가치 효과가 큰 것으로 나타났다.

셋째, 운영준비 및 기초연구단계(운영초기투자기) 중 창 출되는 부가가치의 약 $3.2 \%(3.6 \%)$ 에 해당하는 7 억원 $(6.6$ 억원)은 정부의 순세입으로 환류되는 효과도 있는 것으로 분석되었다.

넷째, 운영준비 및 기초연구기간(2009-2015년) 중 경제 적 파급효과가 큰 생산부문은 연구, 사업관련 전문서비 스, 정밀기기, 음식·숙박, 도소매, 전자기기 등의 순으로 나타났고, 운영초기투자기(2013-2018년) 중에는 사업관련 전문서비스, 기타사업서비스, 연구, 정밀기기, 전자기기부 분품 등의 순으로 나타났다. 
다섯째, 부가가치의 경우 운영준비 및 기초연구기간 (2009-2015년) 중 연구, 사업관련 전문서비스, 정밀기기, 도소매, 부동산 등의 순으로 파급효과가 큰 것으로 나타났 고, 운영초기투자기(2013-2018년) 중의 경제적 파급효과 는 사업 관련 전문서비스, 기타사업서비스, 연구, 정밀기 기, 부동산, 도소매 등의 순으로 파급효과가 큰 것으로 분 석되었다.

\section{운용해양시스템 “운영”의 국민경제적 파급효과}

운용해양시스템 구축 이후에 경제적 편익이 예상되는 산업을 중심으로 경제성장 효과를 기대할 수 있다. 이 경 제성장 효과는 운용해양시스템의 구축에 기인하여 발생하 기 때문에 산업연관분석 체계 하에서 일종의 공공투자 사 업에 의한 외생적인 수요의 창출로 간주할 수 있다. 그리 고 운용해양시스템 구축 이후 외생적 수요증가 요인이 발 생하는 산업은 앞서 Table 2에서 운용해양시스템 이용으 로 경제적 편익이 발생할 것으로 예상되는 경제활동부문 중에서 선택하는 것이 타당할 것이다.

Table 3은 운용해양시스템 구축으로 예상되는 경제적 편익 발생부문을 광범위하게 해석한 “대규모 시나리오”와 보수적으로 해석한 “소규모 시나리오”의 두 가지로 구분 하고 있다. 대규모 시나리오와 소규모 시나리오에 속한 생 산활동부문이 2007년 현재 우리나라 전산업에서 차지하 는 부가가치 비중은 각각 $39.4 \%$ 와 $8.6 \%$ 수준이다. 각 시
나리오에서 운용해양시스템 운영시 예상되는 개별 산업의 투입증가 효과는 동 시스템이 해당 산업에 미칠 것으로 예상되는 경제적 편익의 크기에 따라 외생적 수요증가가 $0.1 \%$ 인 산업(요표시), $0.05 \%$ 인 산업( $\bigcirc$ 표시), $0.025 \%$ 인 산업 $(\triangle$ 표시) 등 세 가지 척도로 구분하였는데, 이 같은 가정을 적용하였을 때 운용해양시스템 구축으로 발생하는 외생적 투입의 증가는 대규모 시나리오의 경우 5,067.7억 원, 소규모 시나리오의 경우 $1,503.5$ 억원 수준이다.

이상과 같은 시나리오를 토대로 계산한 운용해양시스템 “운영”의 생산, 부가가치, 고용 및 세수 효과가 Table 4에 정리되어 있다.

첫째, 운용해양시스템 운영에 의한 예측정보 개선의 잠 재적 편익을 계산한 결과 산업연관효과를 감안할 경우 1조 1,161.5억원(대규모 시나리오) 및 3,276.9억원(소규모 시나리오)에 달하는 것으로 추정된다. 이는 동 시스템 구 축에 소요될 것으로 예상되는 2009-2018년 기간 중 투자 소요예산 총액 394억원의 약 28.3배(대규모 시나리오) 및 8.3배(소규모 시나리오)에 달하는 규모로 운용해양시스템 구축 사업은 산술적인 의미에 있어서도 경제성이 충분한 것으로 평가할 수 있다. 물론 운용해양시스템 구축의 외생 적인 투입 증가효과 발생이 연간 지속적으로 발생한다고 가정하는 것은 비현실적인 것으로 판단되며, 따라서 여기 서 제시한 수준의 산업연관효과가 해마다 발생한다고 보 기는 어렵다.

Table 3. Exogenous growth scenarios of the operation of KOOS

\begin{tabular}{|c|c|c|c|}
\hline \multirow{2}{*}{ Industrial sectors } & \multirow{2}{*}{$\begin{array}{c}\text { \% of gross value added } \\
\text { (GVA) }\end{array}$} & \multicolumn{2}{|c|}{ Input scenario } \\
\hline & & Big input & Small input \\
\hline Agricultural products & 1.83 & () & \\
\hline Fishery products & 0.22 & (2) & (2) \\
\hline Apparels and fibers & 0.84 & $\triangle$ & \\
\hline Precision instruments & 0.38 & $\bigcirc$ & \\
\hline Electric services & 1.44 & $\triangle$ & \\
\hline Gas and water supply & 0.70 & $\triangle$ & \\
\hline Building construction and civil enginering & 4.95 & O & \\
\hline $\begin{array}{l}\text { Eating and drinking places, and hotels and other } \\
\text { lodging places }\end{array}$ & 2.73 & $\bigcirc$ & \\
\hline Land transport & 2.28 & (a) & \\
\hline Water transportation Air transportation & 0.74 & (a) & () \\
\hline Finance and insurance & 6.78 & $\triangle$ & \\
\hline Research services & 1.91 & (a) & (2) \\
\hline Professional business services & 3.72 & (a) & \\
\hline Other business services & 2.13 & (a) & \\
\hline Public administration and defense & 5.70 & (a) & () \\
\hline Medical and health services & 3.08 & () & \\
\hline Subtotal of GVA(\%) & & 39.4 & 8.6 \\
\hline
\end{tabular}

Note: $($ ),$\bigcirc$ and $\triangle$ denote, assumingly and respectively, $0.1 \%, 0.05 \%$ and $0.025 \%$ increasing sectors of exogenous demand with the operation of KOOS. 
Table 4. Macroeconomic impact of KOOS in the operational phase

Unit: 1 million KRW, Persons

\begin{tabular}{|c|c|c|c|c|c|c|c|c|}
\hline \multirow[b]{2}{*}{$\begin{array}{l}\text { Industrial } \\
\text { sectors }\end{array}$} & \multicolumn{4}{|c|}{ Economic impact under big input scenario } & \multicolumn{4}{|c|}{ Economic impact under small input scenario } \\
\hline & $\begin{array}{c}\text { Total } \\
\text { Output } \\
\text { impact }\end{array}$ & $\begin{array}{c}\text { GVA } \\
\text { impact }\end{array}$ & $\begin{array}{c}\text { Total } \\
\text { Emp. } \\
\text { impact }\end{array}$ & $\begin{array}{c}\text { Fiscal } \\
\text { revenues } \\
\text { impact }\end{array}$ & $\begin{array}{c}\text { Total } \\
\text { Output } \\
\text { impact }\end{array}$ & $\begin{array}{c}\text { GVA } \\
\text { impact }\end{array}$ & $\begin{array}{c}\text { Total } \\
\text { Emp. } \\
\text { impact }\end{array}$ & $\begin{array}{c}\text { Fiscal } \\
\text { revenues } \\
\text { impact }\end{array}$ \\
\hline $\begin{array}{l}\text { Agriculture, fishery } \\
\text { and mining }\end{array}$ & 89,359 & 56,681 & 2,705 & $-17,338$ & 21,471 & 11,992 & 346 & $-5,373$ \\
\hline Manufacturing & 288,514 & 70,839 & 906 & 16,282 & 70,469 & 17,355 & 209 & 4,809 \\
\hline Utilities & 31,326 & 11,670 & 45 & 882 & 4,444 & 1,706 & 6 & 130 \\
\hline Construction & 56,492 & 25,404 & 657 & 3,889 & 1,877 & 844 & 22 & 130 \\
\hline Services & 650,455 & 342,178 & 7,415 & 12,762 & 229,428 & 118,450 & 1,982 & 2,566 \\
\hline Total & $1,116,145$ & 506,772 & 11,727 & 16,476 & 327,690 & 150,347 & 2,566 & 2,260 \\
\hline Output multiplier & \multicolumn{4}{|c|}{2.20} & \multicolumn{4}{|c|}{2.180} \\
\hline Tax/GVA(\%) & \multicolumn{4}{|c|}{$(3.3 \%)$} & \multicolumn{4}{|c|}{$(1.5 \%)$} \\
\hline
\end{tabular}

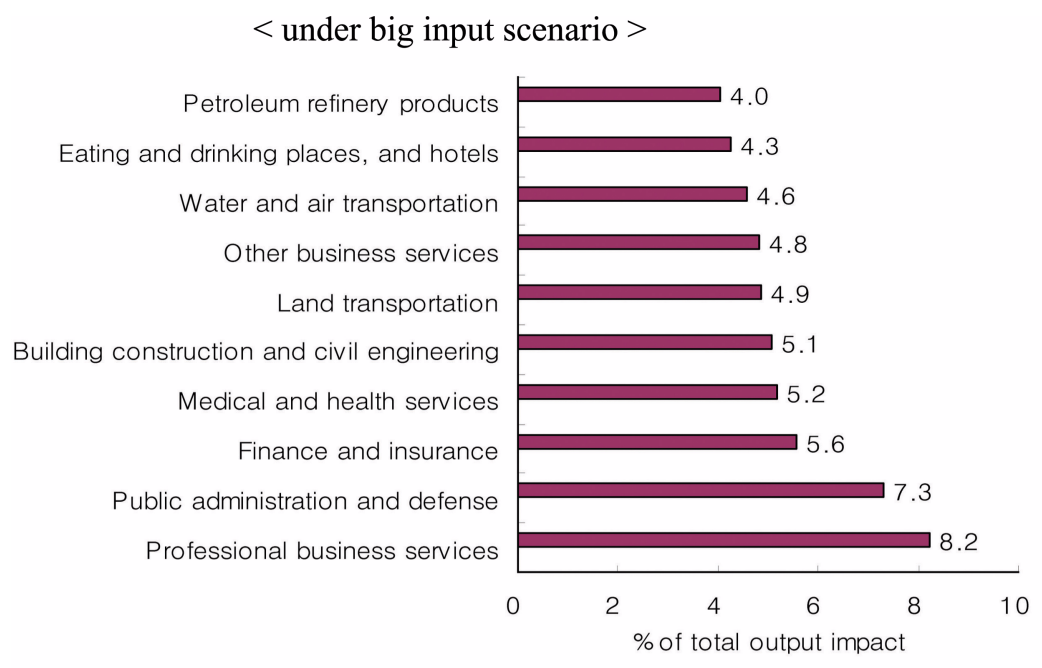

$<$ under small input scenario $>$

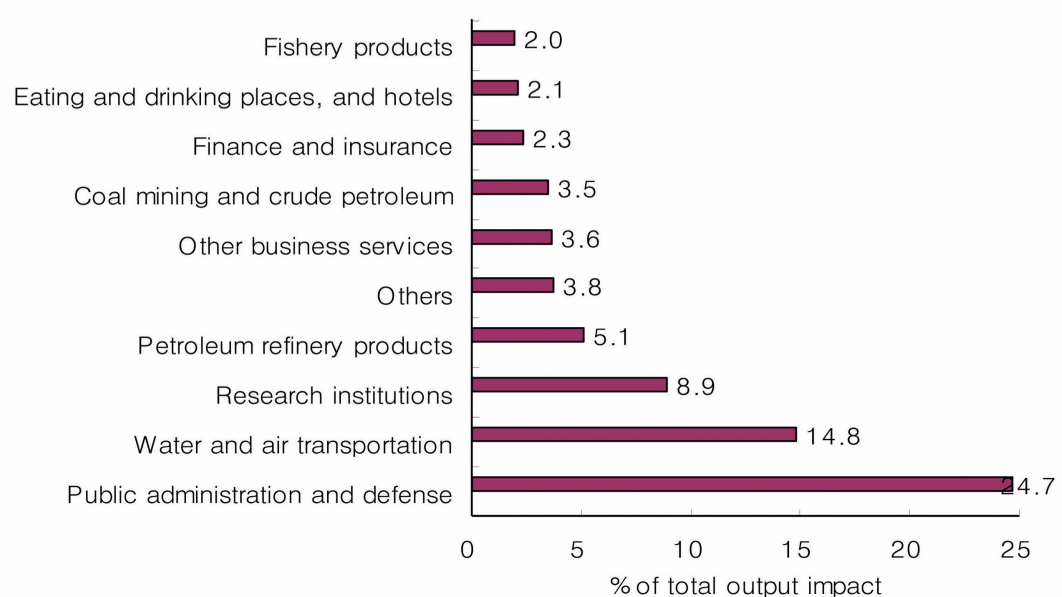

Fig. 5. Top 10 sectors with the highest impact contribution to total output of the KOOS operation.

둘째, 부문별로는 대규모 시나리오 하에서 관측시스템 개선, 해양정보의 전달 및 배포시스템 구축, 운용해양예보
시스템 운영이 포함된 서비스업, 제조업 부문의 순으로 생 산파급 및 부가가치 효과가 큰 것으로 나타났으며, 운영으 
로 창출되는 부가가치의 약 $3.3 \%$ 에 해당하는 164.8 억원 은 정부의 순세입으로 환류되는 효과도 있는 것으로 분석 되었다.

셋째, 소규모 시나리오 하에서도 역시 서비스업과 제조업 순으로 생산 및 부가가치 효과가 큰 것으로 나타났으나, 창 출된 부가가치 중 정부 순세입으로 환류되는 비율은 대규 모 시나리오의 절반 수준에 못 미치는 $1.5 \%$ (22.6억원)로 나타났다.

넷째, Fig. 5와 같이 대규모 시나리오 하에서 운용해양 시스템 운영으로 인한 생산유발효과를 세부 산업부문별 로 살펴보면 경제적 파급효과가 큰 부문은 사업관련 전문 서비스, 공공행정 및 국방, 금융 및 보험, 의료 및 보건, 건축 및 건설 등의 순으로 나타났다. 부가가치의 경우는 선박, 섬유사 및 직물, 기타 비금속광물제품, 비료 및 농 약, 농림어업서비스 등의 순으로 파급효과가 큰 것으로 분석되었다.

다섯째, 소규모 시나리오 하에서 운용해양시스템 운영 으로 인한 생산유발효과를 세부 산업부문별로 살펴보면 경제적 파급효과가 큰 생산부문은 공공행정 및 국방, 수상 및 항공운송, 연구기관 등의 순으로 나타났다. 부가가치 효과의 경우 전체부가가치 창출효과 중에서 역시 공공행 정 및 국방 부문이 차지하는 비율이 제일 높았으며, 이어 서 연구기관, 수상 및 항공운송 부문의 순으로 파급효과가 큰 것으로 분석되었다.

\section{운용해양시스템의 정책적 평가}

다음에서는 운용해양시스템의 경제성 분석에서 다루어 지지 않았으나 이 사업의 타당성을 평가하는데 고려하여 야 할 정책적인 평가요소들을 점검해 보기로 한다. 정책적 평가내용은 해당사업 내용과 무관하게 모든 예비타당성조 사 대상 사업에 공통적으로 적용되는 '기본평가항목'과 운 용해양시스템이라는 고유 사업에만 적용되는 '사업특수 평가항목'으로 구분하여 수행할 수 있는데, 이를 위해 한 국개발연구원(2008) 메뉴얼에 근거하여 사업의 시행 여부 를 판단하는 데 있어서 반드시 고려해야 할 평가요소들에 대하여 분석해 본다.

\section{기본펑가항목 분석}

첫째, 지역균형발전이라는 상위의 국가정책적 측면에 서 볼 때 운용해양시스템은 산업적으로 낙후된 어업·농 업 등 1 차산업을 보호하고 도서-연안지역 거주자들의 안전과 경제생활을 도모하는 등의 직접적인 혜택을 유발 하기 때문에 지역균형발전을 촉진하는 사업으로 평가할 수 있다.

둘째, 운용해양시스템 사업의 경우 특정 사업주체가 단 독으로 단기간에 계획을 수립하여 추진하는 것이 아니라
이미 2001년에 수립된 실시간 해양관측망 구축기본계획 이라는 상위 계획의 보완이라는 연장선에 있는 사업으로 정책적 일관성을 가지고 추진되고 있다고 평가할 수 있다.

셋째, 통상적인 공공사업 추진상 대표적인 위험요인으 로는 재원조달 문제와 환경문제를 들 수 있다. 운용해양시 스템의 구축은 다른 국토개발 사업과는 비교할 수 없을 정도로 소규모이기 때문에 재정부담이 예상되는 사업은 아니다. 프로그램 설계와 전산장비의 구축 등 기본적인 인 프라 구축에 중앙정부의 자체 예산으로 당위성을 갖춘 지 원이 가능하다고 판단된다. 또한 운용해양시스템은 인간 의 안전한 활동과 경제생활을 보호해 주기 위한 일종의 소프트웨어적인 사업의 구축이기 때문에 사업추진상의 대 표적인 위험요인 중 하나인 환경문제로 인한 지역민원 발 생 가능성이 전혀 없다.

\section{사업특수 평가항목 분석}

첫째, 운용해양시스템은 미국, 유럽, 일본 등 선진국에 서 이미 1990년대 초부터 상용화 단계에 있는 기술로서 기술적 타당성과 실현 가능성이 높은 사업이라고 판단된 다. 우리의 경우 아직 사용자가 비용을 지불하고 해양정보 를 활용하는 단계에는 이르지 못했으나, 기존의 해양정보 를 소프트웨어적으로 재가공하여 이를 수요자에게 제공하 는 방식의 운용해양시스템 운영은 충분히 단기에도 실현 가능한 사업으로 예상되고 있다.

둘째, 사업주체의 적정성과 유관 기관간 협조체계 면에 서 볼 때 $\ulcorner$ 운용해양시스템 구축 개발 연구사업 $\lrcorner$ 은 해양 관측을 위해 국토해양부·석유공사·기상청-해양조사 원·수산과학원 · 해양연구원 등의 공동의 이해와 관심사 에 따른 참여로 이루어지고 있다. 현재 시점에서 한국해양 연구원 주도로 운용해양시스템 구축 개발사업이 추진되는 것은 적정하다고 판단되나, 향후 양질의 해양자료에 대한 국가적 수요가 증가하면 해양정보서비스 산업이 활성화되 면서 민간기업의 참여도 유도할 수 있을 것으로 전망된다.

셋째, 「운용해양시스템 구축 개발 연구」는 기존에 제 공되어 오지 못한 새로운 서비스를 창출하여 제공하기 위 한 목적으로 추진되는 사업으로 기존의 연구개발 과제 및 대상기술과의 중복성 문제는 없다고 판단된다. 따라서 부 족한 국내 해양자료융합기법 연구에 대한 인력 및 인프라 확충을 지원하고, 동북아 국가들과 동해·황해 등 인근해 자료를 실시간으로 교환하는 체제를 마련하기 위해서는 해양관측 자료를 융합하여 실시간으로 예보할 수 있는 체 계를 갖추는데 대한 국고지원이 필요하다.

\section{6. 결 론}

운용해양시스템 개발 사업은 연안재해, 해양오염 사고, 
안전항해 지원 등 해양에서의 각종 문제 해결 및 해양 정 보의 최종수요자인 국가기관·산업체·민간이 각종 해양 활동에서 필요로 하는 해양환경 변화 현황과 예측정보를 생산·제공하는 메커니즘의 구축을 의미한다. 운용해양 시 스템 개발은 기술적으로 우리 주변 해역에 적합한 한국형 해양예측모델을 독자적으로 구축하여 해양과학기술 국가 경쟁력을 제고한다는 의미를 가질 뿐만 아니라, 경제적으 로는 해일·해수범람·태풍 등에 의한 연안 해양재해 및 유류오염·적조 등 해양환경 오염에 대하여 신속한 해양 현황 및 예측정보를 제공함으로써 피해 경감효과를 기대 할 수 있음을 의미한다.

본고에서는 운용해양시스템 구축 사업의 경제적 효과에 대한 시나리오 분석을 통해 화폐적인 가치를 산출해 보았 다. 그러나 동 사업의 타당성과 관련해서는 통상적인 국가 사업의 평가 범주와 같이 화폐적 비용-편익의 관점에서만 접근하는 우를 범해서는 안된다. 현 단계에서 화폐적 가치 로 시현되지 않은 해양에서의 자연재해 경감 및 위기관리 능력 향상, 국민 보건과 건강 증진 등 국민의 생명과 재산 보호에 대한 기여를 무시할 수 없기 때문이다.

중장기적으로 운용해양시스템(KOOS)은 수요자 중심의 연안 및 해양에서의 단기예측정보 제공과 함께 기후변화 등 중장기 예측 정보까지도 제공할 수 있는 시스템을 갖 추어 나가야 할 것으로 판단된다. 뿐만 아니라 현재 추진 중인 $\mathrm{KOOS}$ 는 우리 주변 해역은 물론 중장기적으로 동북 아지역 해양(동해, 황해, 동중국해)에서의 안전한 해양경 제 활동을 보장하기 위한 포괄적인 해양예보 능력을 갖추 어 나가야 할 것이다. 나아가 KOOS는 활용도를 제고하기 위해 전지구해양관측시스템 $(\mathrm{GOOS})$ 과 같은 국제사회의 수요에도 부응할 수 있도록 동북아 역내 운용해양학시스 템을 구축하는 방향으로 정책을 수립해 나가야 할 필요가 있다. 이를 위해 장기적으로는 정부출연 연구기관에서 수 행하는 운용해양시스템 개발 결과를 독립적으로 운영해 나갈 주체를 모색하는 것도 필요할 것으로 전망된다.

\section{사 사}

본 연구는 국토해양부 연구개발사업 “운용해양(해양예 보) 시스템 연구”의 연구비 지원에 의해 수행되었습니다.

\section{참고문헌}

국토해양부 중앙해양안전심판원 (2009) 2008년 해양사고 분

\section{석보고서. $41 \mathrm{p}$}

김세환, 황진태 (2008) 기후변화가 보험산업에 미치는 영향 과 대응과제. 보험동향 가을호:1-14

노용환, 유경원 (2009) 기후변화와 가계의 위험관리: 가계 자 산구성을 중심으로. 보험금융연구 20(1):107-149

밀러·블레어(Ronald E. Miller and Peter D. Blair) (2006) 산 업연관분석: 기본 원리와 응용. 한국은행 역, 서울, $626 \mathrm{p}$ 이동영, 박광순, Jun Shi (2009) 한반도 주변 해역 운용해양 시스템 구축 방향. Ocean and Polar Res 31(4):361-368

통계청 (2009a) 2008년 농가 및 어가경제조사 결과. http:// kostat.go.kr. Accessed 14 Apr 2009

통계청 (2009b) 2008년 어업생산동향 조사 결과. http:// kostat.go.kr. Accessed 10 Feb. 2009

통계청 KOSIS 국가통계포털. www.kosis.kr

한국개발연구원 (2008) 도로 - 철도 부문 사업의 예비타당성 조사 표준지침 수정 · 보완 연구(제 5판). 서울, $649 \mathrm{p}$

한국은행 (2009) 2007년 산업연관표. 서울, 577 p

한기주 (2007) 기후변화가 산업부문에 미치는 경제적 영향. KIET산업경제 9월호:52-66, 산업연구원

해양수산부 (2007) 국가해양관측망 기본 계획에 따른 운용해 양학 시스템 구축 계획. 서울, $223 \mathrm{p}$

Adams R, Brown M, Colgan C, Flemming N, Kite-Powell H, McCarl B, Mjelde J, Solow A, Teisberg T, Weiher R (2000) The economics of sustained ocean observations: benefits and rationale for public funding. National Oceanic and Atmospheric Administration (NOAA), U.S. Department of Commerce, Washington, DC, $52 \mathrm{p}$

Australian Academy of Technological Sciences and Engineering (2006) Economics of Australia's sustained ocean observation system, benefits and rationale for public funding. Australia, $44 \mathrm{p}$

Kite-Powell H, Colgan C, Weiher R (2003) Economics of an integrated ocean observing system. Mar Technol Soc J 37(3):55-66

Willis Z (2009) The business case for improving NOAA's management and integration of ocean and coastal data. Integrated Ocean Observing System (IOOS) of National Oceanic and Atmospheric Administration (NOAA), U.S. Department of Commerce, Washington, DC, $73 \mathrm{p}$

Received May 7, 2010

Revised Jul. 2, 2010

Accepted Jul. 22, 2010 